\title{
4Limburg: Kwaliteit re-integratie data CBS
}

Citation for published version (APA):

Künn, A., \& Jacobs, B. (2019). 4Limburg: Kwaliteit re-integratie data CBS. ROA. ROA Technical Reports No. 004 https://doi.org/10.26481/umarot.2019004

Document status and date:

Published: 17/03/2019

DOI:

10.26481/umarot.2019004

Document Version:

Publisher's PDF, also known as Version of record

\section{Please check the document version of this publication:}

- A submitted manuscript is the version of the article upon submission and before peer-review. There can be important differences between the submitted version and the official published version of record.

People interested in the research are advised to contact the author for the final version of the publication, or visit the DOI to the publisher's website.

- The final author version and the galley proof are versions of the publication after peer review.

- The final published version features the final layout of the paper including the volume, issue and page numbers.

Link to publication

\footnotetext{
General rights rights.

- You may freely distribute the URL identifying the publication in the public portal. please follow below link for the End User Agreement:

www.umlib.nl/taverne-license

Take down policy

If you believe that this document breaches copyright please contact us at:

repository@maastrichtuniversity.nl

providing details and we will investigate your claim.
}

Copyright and moral rights for the publications made accessible in the public portal are retained by the authors and/or other copyright owners and it is a condition of accessing publications that users recognise and abide by the legal requirements associated with these

- Users may download and print one copy of any publication from the public portal for the purpose of private study or research.

- You may not further distribute the material or use it for any profit-making activity or commercial gain

If the publication is distributed under the terms of Article $25 \mathrm{fa}$ of the Dutch Copyright Act, indicated by the "Taverne" license above, 


\section{Maastricht University $\&$ ROA}

\section{Limburg: Kwaliteit re-integratie data CBS}

Annemarie Künn-Nelen

Babs Jacobs

\section{ROA Technical Report}

ROA-TR-2019/4

Researchcentrum voor Onderwijs en Arbeidsmarkt | ROA Research Centre for Education and the Labour Market / ROA 


\title{
4Limburg: Kwaliteit re-integratie data CBS
}

\author{
Annemarie Künn-Nelen \\ Babs Jacobs
}

ROA-TR-2019/4

September 2019

\section{LIMBURG}

Dit technisch rapport is een onderdeel van het meerjarenprogramma 4 Limburg dat een bijdrage wil leveren om de Limburgse samenleving meer duurzaam, vitaal en inclusief te maken. Het doel van dit programma is om, in nauwe samenwerking met de Universiteit Maastricht, Provincie Limburg en ketenpartners zoals gemeenten, UWV en bedrijfsleven, via een trendbreuk de arbeidsparticipatie én de vitaliteit in Limburg naar een hoger niveau te tillen.

Research Centre for Education and the Labour Market

Maastricht University

P.O. Box 616, 6200 MD Maastricht, The Netherlands

$\mathrm{T}+31433883647 \mathrm{~F}+31433884914$

secretary-roa-sbe@maastrichtuniversity.nl

www.roa.nl 


\section{INHOUD}

\section{Bladzijde}

1 Inleiding

2 Beschikbare gegevens

3 Re-integratie data van het CBS 7 3.1 SRG data 2005-2018 7 3.2 SRG data vanaf 2019

4 Kwaliteit Limburgse gemeentelijke re-integratie data van het CBS voor 2016-2017

4.1 Eerste kwaliteitscheck: vergelijking externe data 4.2 Tweede kwaliteitscheck: specifieke re-integratie voorzieningen 4.3 Derde kwaliteitscheck: vergelijking voor en na verbetering 12 4.4 Samenvatting kwaliteit SRG-data voor Limburgse gemeenten in 2016/2017 15

5 Analyses 17

6 Reflectie op veranderslag $\quad 19$

Bijlage A 

In dit rapport zal in kader van het '4Limburg' project de kwaliteit van de re-integratie statistieken van de Limburgse gemeenten (2016/2017) geleverd door het Centraal Bureau voor de Statistiek (CBS) worden vastgesteld. Aanleiding hiervoor is dat gedurende deze periode niet alle gemeenten beschikten over kwalitatief goede of eenduidige data. Allereerst zal kort worden besproken op welke gebieden gegevens beschikbaar zijn voor de provincie Limburg. Indien niet over alle inwoners informatie beschikbaar is voor een bepaald kenmerk, zal dit besproken worden in dit hoofdstuk.

Vervolgens zal specifiek ingezoomd worden op de re-integratie voorzieningen zoals die is gemeten door het CBS. Hierbij wordt allereerst beschreven wat de situatie is voor de voor 4 Limburg beschikbare data (2016/2017). Ook wordt de veranderslag die bij het CBS in gang gezet is sinds januari 2019 beschreven.' Daarna wordt nagegaan wat de kwaliteit is van de 2016/2017 data en welke implicaties deze kwaliteit heeft voor het geven van een goed beeld van de rol van de gemeentelijke re-integratievoorzieningen bij de kans op re-integratie.

We hebben drie mogelijkheden om te kwaliteit van de CBS data m.b.t. re-integratie voorzieningen te bekijken. Allereerst vergelijken we het percentage bijstandontvangers dat een re-integratievoorziening gehad heeft in december 2016 met een externe databron van Thönissen Management en Advies. Ook kijken we naar het percentage re-integratievoorzieningen dat bij de koppeling van de gemeentelijke administratie naar de statistieken re-integratie gemeenten (SRG) van het CBS als'overige voorziening'geclassificeerd is. Als laatste bekijken we het aantal re-integratievoorzieningen per gemeente vlak voor en na de recente verbeterslag van het CBS. Bij de bespreking van deze kwaliteitschecks richten we ons op tien vooraf geselecteerde gemeenten: Venlo, Roermond, Heerlen, Beesel, Venray, Weert, Leudal, Onderbanken-Nuth-Schinnen. Voor de overige Limburgse gemeenten is in de bijlage ook informatie opgenomen met betrekking tot de kwaliteitschecks.

Voor de gemeenten waar de kwaliteit van de 2016/2017 als voldoende beschouwd wordt, is vervolgens een eenvoudige analyse gedraaid. Er is gekeken in hoeverre deelname aan een re-integratietraject gerelateerd is aan re-integratiekansen.

Tot slot wordt gereflecteerd op het effect van deze verbeteringen op cijfers over gemeentelijke re-integratie inspanningen. Dit met als doel om in te schatten of de data vanaf 2019 mogelijk interessant is voor vervolgonderzoek binnen 4Limburg.

1 De input voor de beschrijving van deze veranderslag is geleverd door het CBS. Het ROA doet vervolgens in het rapport een uitspraak over de impact van deze kwaliteitsverbetering en de bruikbaarheid van de re-integratie cijfers voorafgaand aan deze revisie. Ook reflecteert het ROA op de verbeterslag. Het CBS heeft vervolgens deze uitspraken gereviewd. 



\section{BESCHIKBARE GEGEVENS}

De registerdata die ten behoeve van het '4Limburg' project door het CBS verstrekt is, bevat informatie op tal van terreinen. Gezien het grote aantal kenmerken die in het bestand aanwezig zijn, zijn deze kenmerken ingedeeld in zeven gebieden. Er is informatie beschikbaar op de volgende gebieden: gezondheid, opleiding, gezin, financiële situatie, werk en uitkeringen, re-integratie voorzieningen en overige (persoons-)kenmerken. De kenmerken worden in de meeste gevallen maandelijks gemeten, in sommige gevallen is er echter alleen jaarlijkse informatie beschikbaar. Het gaat daarbij om de jaren 2016 en 2017.

Drie kenmerken vallen onder het terrein 'gezondheid'. Allereerst is er informatie beschikbaar over het medicatiegebruik van alle inwoners in Limburg. Hierbij gaat het om de geneesmiddelen-verstrekking die wordt vergoed vanuit de basis zorgverzekering. Daarnaast is, indien van toepassing, zowel de mate van arbeidsongeschiktheid als de oorzaak van de arbeidsongeschiktheid bekend.

Opleiding wordt gemeten aan de hand van twee soortgelijke kenmerken: 1) het hoogst voltooide opleidingsniveau gemeten in drie categorieën en 2) het onderwijsniveau uitgesplitst naar 18 categorieën. Het CBS heeft deze variabelen samengesteld vanuit verschillende onderwijsregisters en gegevens van de Enquête Beroepsbevolking (EBB). Echter zijn de onderwijsregisters nog relatief nieuw (zie Tabel 1), waardoor voor de oudere cohorten informatie over hun hoogst voltooide onderwijsniveau kan ontbreken.

TABEL 1 Samenstelling van meting hoogst voltooide opleiding

\begin{tabular}{|c|c|}
\hline Bron: & Beschikbaar vanaf: \\
\hline \multirow[t]{2}{*}{ Centraal register van inschrijvingen in het hoger onderwijs (CRIHO) } & Vanaf 1983 (wo) \\
\hline & Vanaf 1986 (hbo) \\
\hline \multirow[t]{3}{*}{ Onderwijsnummerbestanden voortgezet onderwijs } & Vanaf schooljaar 2003/'04 \\
\hline & Vanaf 2004/'05 (mbo) \\
\hline & Vanaf 2005/'06 (volwasseneducatie) \\
\hline $\begin{array}{l}\text { Onderwijsnummerbestanden basisonderwijs (WP0) en speciaal onderwijs } \\
\text { (WEC) }\end{array}$ & Vanaf schooljaar 2005/'06 \\
\hline $\begin{array}{l}\text { Bestanden met opleidingsgeschiedenissen zoals opgegeven door } \\
\text { werkzoekenden bij het UWV WERKbedrijf }\end{array}$ & Vanaf 2010 \\
\hline Enquête Beroeps bevolking (EBB) & Vanaf 2004 \\
\hline
\end{tabular}

Hoewel informatie over inschrijvingen in het hoger onderwijs vanaf de jaren ' 80 van de vorige eeuw zijn bijgehouden, is informatie die betrekking heeft op het voortgezet en middelbaar beroepsonderwijs pas vanaf het begin van deze eeuw geregistreerd. Vanaf 2004 worden de onderwijsgegevens in het register aangevuld met opleidingsgegevens uit de Enquête Beroeps Bevolking (EBB). Dit is ook terug te zien in de beschikbare registerinformatie. Van ongeveer $38 \%$ van de mensen in de provincie Limburg is het hoogst voltooide opleidingsniveau in 2016 onbekend. Wanneer alleen naar de beroepsbevolking wordt gekeken, neemt dit percentage af naar ongeveer $34 \%$. Hoewel dit nog steeds een aanzienlijk percentage is, zal dit naar verwachting verder afnemen naarmate er meer jongere cohorten bijkomen. 
Om gebruik te kunnen maken van het hoogst voltooide opleidingsniveau kunnen een tweetal strategieën worden toegepast. Aangezien de registers vanaf 1986 alle inschrijvingen in het hoger onderwijs bijhouden, is de eerste strategie om alleen een onderscheid te maken tussen wel of geen hoger onderwijs genoten. Door het hoogst voltooide opleidingsniveau af te zetten tegenover de leeftijdscategorieën, is te zien tot welke leeftijd dit kenmerk voldoende vulling heeft. Uit onze gegevens komt naar voren dat het percentage personen met een hoog opleidingsniveau, dat wil zeggen hbo of wo, begint af te nemen vanaf de categorie 46 tot 50 -jarigen. ${ }^{2}$ Bij deze laatstgenoemde groep is ook een toename te zien in het percentage personen van wie het onderwijsniveau 'onbekend' is. Het gaat hierbij om een verschil van ongeveer $6 \%$ ten opzichte van de 41 tot 45 -jarigen. Bij de leeftijdscategorieën naar het percentage 'onbekend'verder toe naar meer dan de helft in de categorie 61 tot 65 -jarigen. Een nadeel van deze strategie is dat de groep personen die geen hbo of wo heeft afgerond niet homogeen is. Hierin zitten zowel de personen met een mbo-opleiding als personen met een lager onderwijsniveau, wat interessant kan zijn met betrekking tot uitkeringsafhankelijkheid en re-integratie.

De tweede strategie is dan ook om naast het hoger onderwijs te onderzoeken vanaf welke leeftijd het voortgezet onderwijs (vo) en mbo meegenomen kan worden in de opsplitsing van hoogst voltooide opleidingsniveau. Uit onze gegevens komt naar voren dat bij de leeftijdscategorie 31 tot met 35 jaar het percentage personen met een 'onbekend' opleidingsniveau bijna verdubbeld ten opzichte van de leeftijdscategorie 26 tot 30-jarigen, terwijl het percentage personen met een middelbaar onderwijsniveau in deze leeftijdsgroep verder afneemt. ${ }^{3}$ Vanaf de leeftijdscategorie 36 tot 40-jarigen neem het percentage 'onbekend' nog verder toe naar een kwart van de categorie. Dit zijn aanwijzingen dat tot en met de 30-jarigen er voldoende informatie is over onderwijsgegevens uit het vo en mbo. Aangezien alleen van de jongere cohorten, dit soort informatie beschikbaar is, heeft dit echter als nadeel dat de personen ouder dan 30 jaar niet kunnen worden meegenomen.

Over het gezin zijn ook een aantal kenmerken beschikbaar vanuit het register. Zo is bekend wat de migratieachtergrond van een persoon is. Hierbij wordt onderscheid gemaakt tussen Nederlandse achtergrond, eerste en tweede generatie migratieachtergrond. Het type huishouden is opgesplitst naar acht categorieën, te weten: eenpersoonshuishouden, niet-gehuwd paar zonder kinderen, gehuwd paar zonder kinderen, niet-gehuwd paar met kinderen, gehuwd paar met kinderen, eenouderhuishouden, overig huishouden en institutioneel huishouden. Door naar de kinderbijslag te kijken kan een indicatie worden gegeven van het aantal kinderen in het huishouden. Tot slot, is van de woning van het huishouden bekend of dit een huur- of koopwoning betreft.

De financiële situatie kan in kaart worden gebracht aan de hand van vijftal variabelen. Een indicator van deze situatie is het besteedbaar inkomen van het huishuiden in percentielen. Over eventuele schuldenproblematiek is van een huishouden de hoogte van de schuld bekend. Van zogenaamde institutionele huishoudens is deze informatie niet beschikbaar. Institutionele huishoudens betreffen personen of paren die verblijven in instellingen, inrichtingen of tehuizen. ${ }^{4}$ In de beschikbare register informatie gaat dit om bijna $2 \%$ van de personen in Limburg. Hetzelfde geldt voor huishoudens waarvan het CBS geen gegevens heeft. Van deze personen is de huishoudschuld dan ook niet te berekenen. Naast de huishoudschuld is ook de deelname aan een schuldsanering traject bijgehouden op persoonsniveau. Wat betreft de woning weten we de WOZ-waarde van de eigen woning en de hypotheekschuld.

Een belangrijk terrein waarover zeer uitgebreide registerinformatie beschikbaar is, is de werksituatie en de uitkeringsafhankelijkheid. Allereerst is van een persoon bekend of diegene al dan niet werkzaam is als werk-

2 Een simpele rekeningsom laat zien dat personen die in 1986 een inschrijving hadden aan een hbo of wo-instelling op dat moment ongeveer 18 jaar zouden moeten zijn geweest en dus ongeveer in 1968 (=1986-18) geboren moeten zijn. Dit betekent dat zij in 2016 maximaal 48 (=2016-1968) jaar oud zijn. Aangezien de statistieken van het wo-onderwijs al drie jaar langer beschikbaar zijn (vanaf 1983), lijken de gepresenteerde percentages in de hoofdtekst op deze rekeningsom aan te sluiten.

3 In het register wordt het vo en mbo vanaf 2004 bijgehouden. Ervan uitgaande dat de personen op dat moment tenminste 16 jaar oud waren, zijn zij geboren rond 1988 (=2004-16) of later. In 2016 zullen zij dan ook de leeftijd van 28 jaar (=2016-1988) hebben.

4 Het gaat hierbij om instellingen zoals: verpleeg-, verzorgings-, en kindertehuizen, gezinsvervangende tehuizen, revalidatiecentra en penitentiaire inrichtingen. 
nemer en/of zelfstandige. Indien er sprake is van een baan, is hiervan bekend hoeveel contracturen per week deze omvat, of het een vaste of flexibele arbeidsrelatie is, het type contract, de werkgemeente en de sector. De ontvangen uitkeringen kunnen worden uitgesplitst naar het wel of niet ontvangen van WW-uitkering, bijstandsgerelateerde uitkering of uitkeringen volgens de WAO, WGA, IVA, Wajong en/of Waz.

De re-integratiekenmerken zullen in het volgende hoofdstuk nog uitgebreid besproken worden. De informatie die hierover beschikbaar is, betreft het al dan niet deelnemen aan een gemeentelijke re-integratievoorziening. Daarbij is ook specifieke informatie over de soort inspanning, zoals het aantal werkplekken met begeleiding door een jobcoach, beschutte werkplekken of participatieplaatsen. Tevens worden eventuele (forfaitaire/tijdelijke) loonkostensubsidies, vervoersvoorzieningen voor woon-werkverkeer en WIW5/ID-banen ${ }^{6}$ bijgehouden in het register. Indien de gemeentelijke regeling niet onder een van deze specifieke voorzieningen valt, is deze ingedeeld bij het aantal overige voorzieningen. Tot slot, is bekend of een individu deelneemt aan een re-integratie traject voor arbeidsgehandicapten verzorgd door het UWV.

De overige (persoons-)kenmerken bevatten gegevens met daarin het geslacht, de geboortedatum? ${ }^{7}$, het geboorteland en de huidige woonlocatie. Daarnaast is een kenmerk beschikbaar dat meet waar een persoon het meeste inkomen vandaan heeft. Dit kunnen de volgende bronnen zijn: WW, AO, bijstand, werk als werknemer, werk als zelfstandige, pensioenuitkering, scholier/student zonder inkomen, scholier/student met inkomen en geen inkomen doordat de persoon te jong is. In Figuur 1 is een schematische weergave te zien van de terreinen en kenmerken.

FIGUUR 1 Schematische weergave kenmerken

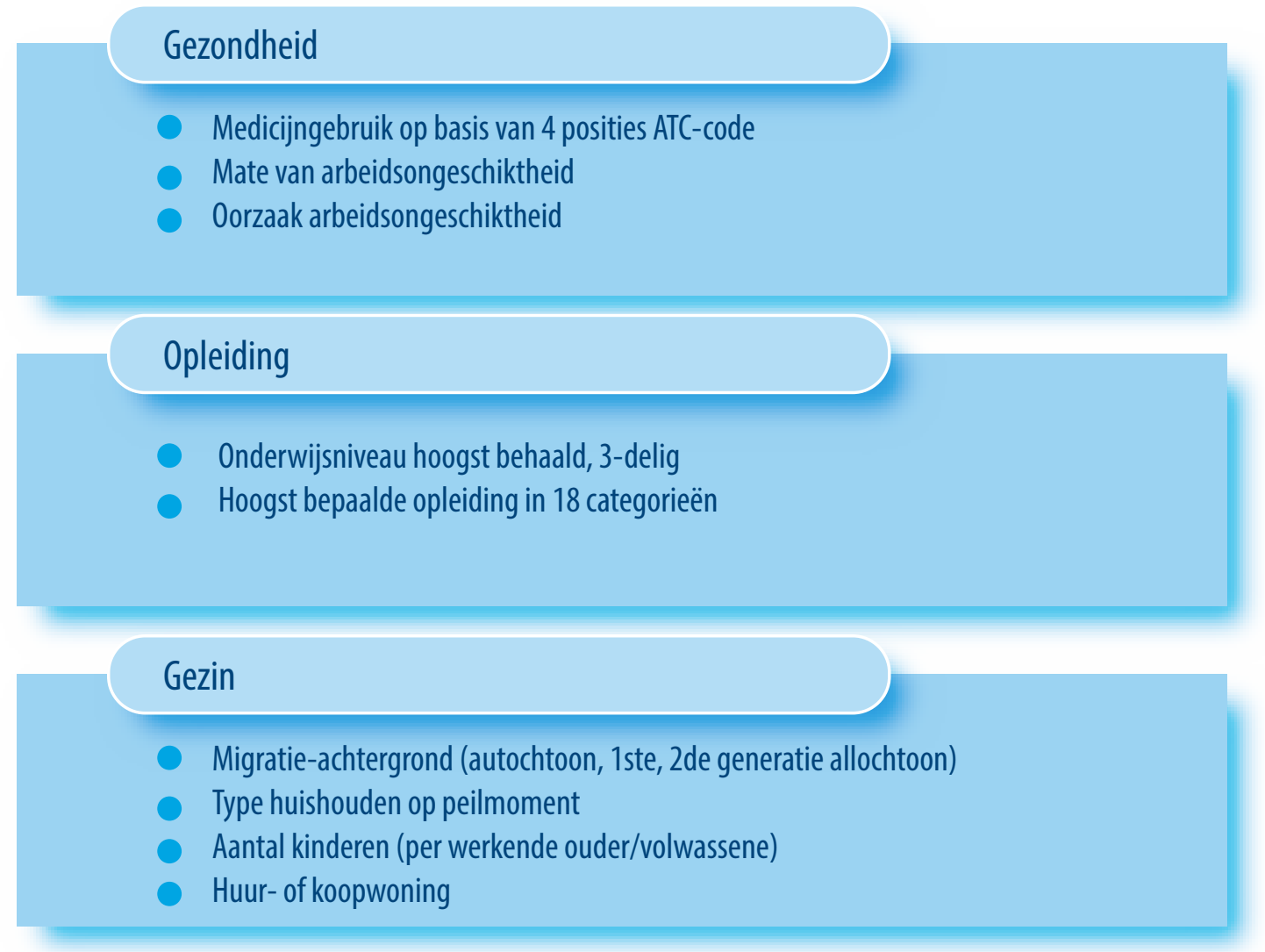

5 Voormalige Wet inschakeling werkzoekenden

Voormalig Besluit in- en doorstroombanen.

7 De geboortedag is op de 1e van de maand gezet. 


\section{Financiële situatie}

- Besteedbaar inkomen van het huishouden in percentielen

- Schulden van het huishouden

- Hypotheekschuld eigen woning van het huishouden

WOZ-waarde eigen woning huishouden

- Deelname aan traject schuldsanering

\section{Werk en Uitkeringen}

Werkt iemand in betreffende maand (als werknemer en/of zelfstandige)

- Aantal contracturen per week

- Vaste of flexibele arbeidsrelatie

- Type arbeidscontract

- Sector van baan

- Werkgemeente

- Ontvangt wel/geen ww-uitkering

- Uitkering wel/niet volgens WAO, WGA, IVA, WAJONG en/ofWAZ

- Persoon heeft wel of geen bijstandsgerelateerde uitkering op peilmoment

\section{Re-integratiekenmerken}

- Deelname aan een gemeentelijke re-integratievoorziening

- Aantal werkplekken met begeleiding door een jobcoach, beschutte werkplekken, forfaitaire loonkostensubsidies, (tijdelijke) loonkostensubsidies, participatieplaatsen, vervoersvoorzieningen voor woon-werkverkeer, wiw/id-banen

- Aantal overige voorzieningen

- Deelname aan een re-integratie traject voor arbeidsgehandicapten verzorgd door het UWV

\section{Overige (persoons-)kenmerken}

- Geslacht

- Geboortedatum van persoon (geboortedag op de 1e van de maand gezet)

- Geboorteland van persoon

- Woonlocatie: gemeente, wijk, buurt

- Waar heeft de persoon het meeste inkomen vandaan in een betreffende maand (ww, ao, bijstand, werk als werknemer, werk als zelfstandige, pensioenuitkering, scholier/student - geen inkomen, scholier student met inkomen, geen inkomen - te jong) 


\section{RE-INTEGRATIE DATA VAN HET CBS}

\subsection{SRG data 2005-2018}

Zoals in vorig hoofdstuk al kort is benoemd, wordt door het CBS data verzameld over de re-integratie inspanningen van gemeenten; de zogenaamde Statistiek Re-integratie door Gemeenten (SRG). Het CBS houdt deze statistieken vanaf 1 januari 2005 bij in opdracht van het ministerie van Sociale Zaken en Werkgelegenheid (SZW). De informatie wordt onder andere gebruikt om de Tweede Kamer te informeren over het gevoerde beleid en onderzoeken en rapportages te maken waarin re-integratievoorzieningen een rol spelen. In de data die het CBS ten behoeve van het ' 4 Limburg' project aan het ROA heeft aangeleverd, zijn de maandelijkse gegevens beschikbaar voor de jaren 2016 en 2017.

Gemeenten dienen verplicht maandelijks statistische gegevens voor de SRG aan te leveren aan het CBS. De gegevens uit de administratie van de gemeenten wordt aan de hand van zogenaamde vertaaltabellen omgezet naar de indelingen van het CBS. In het SRG-bestand wordt van elke persoon die gebruik maakt van een voorziening in de desbetreffende maand, aangegeven van welk type voorziening deze persoon gebruikt maakt. De voorzieningen in de jaren 2016/2017 waren de volgende:

- Loonkostensubsidie op grond van de Participatiewet

- Tijdelijke loonkostensubsidie

- Participatieplaats

- Beschut werk, begeleiding op werkkring/job-coach

- WIW/ID-baan

- Vervoersvoorziening (woon-werk)

- Overige voorziening

- Andere voorziening voor arbeidsbeperkten

- Forfaitaire loonkostensubsidie (vanaf 1 januari 2017 gemeten)

Bij een loonkostensubsidie op grond van de Participatiewet krijgt de werkgever subsidie om een bijstandsgerechtigde in dienst te nemen met een regulier arbeidscontract die langdurig een arbeidsvermogen heeft onder het wettelijk minimumloon (WML). Deze vorm van subsidie kan doorgaan tot aan het pensioen. De tijdelijke loonkostensubsidie is verwant aan de loonkostensubsidie op grond van de Participatiewet. De twee verschillen zijn echter dat de tijdelijke loonkostensubsidie is bedoeld ter ondersteuning van personen die tijdelijk een lager productniveau hebben en er wordt niet gekeken of het arbeidsvermogen onder het WML ligt. Een derde soort loonkostensubsidie is de forfaitaire loonkostensubsidie. Deze subsidie kan ingezet worden als men voornemens is om een loonsubsidie op grond van de Participatiewet in te gaan zetten, maar nog niet de loonwaarde van een persoon hebben vastgesteld. Na zes maanden moet de gemeente de forfaitaire loonkostensubsidie beëindigen. Deze gemeentelijke inspanning wordt pas vanaf 1 januari 2017 bijgehouden.

Personen met een participatieplaats hebben een specifieke vorm van werken, waarbij zij hun uitkering behouden maar geen beloning krijgen voor hun verrichten werkzaamheden. De participatieplaats wordt ingezet in het kader van re-integratie en is bedoeld voor uitkeringsgerechtigden die door persoonlijke werkbelemmeringen een kleine kans hebben tot het toetreden tot de arbeidsmarkt. Zij krijgen bij de participatieplaats dan ook speciale begeleiding. 
Gemeente moeten zelf bepalen wanneer er sprake is van een beschutte werkplaats. Het gaat hierbij voornamelijk om de mate van begeleiding en aanpassingen op de werkplek die door gemeenten worden gedaan. In de meeste gevallen hebben deze personen ook een andere voorziening zoals een jobcoach of loonkostensubsidie. De WIW/ID-banen betreffen de 'oude' gesubsidieerde banen: In-en-Doorstroombanen (ID-banen) en werkervaringsplaatsen voor langdurig werklozen op basis van het besluit Werk inschakeling Werkzoekenden (WIW). Per 1 januari 2004 is het niet meer mogelijk om deel te nemen aan een van deze regelingen.

De vervoervoorziening wordt ingezet indien het lastig is om naar het werk te reizen. Deze regeling is zowel voor personen met als zonder een arbeidsbeperking. Voor arbeidsbeperkten zijn er ook andere voorzieningen ter ondersteuning. Voorbeelden hiervan zijn een doventolk en voorleeshulp. Alle overige voorzieningen die tot de SRG behoren, zijn tot slot ingedeeld in de 'overige voorzieningen'.

In Figuur 2 is voor de eerder genoemde Limburgse gemeenten het percentage van de WW- en bijstandsontvangers $^{8}$ uit 2016 aangegeven dat aan een of meerdere gemeentelijke voorzieningen heeft deelgenomen.

FIGUUR 2 Percentage WW- en bijstandsontvangers dat aan een of meerdere gemeentelijke voorzieningen heeft deelgenomen, 2016

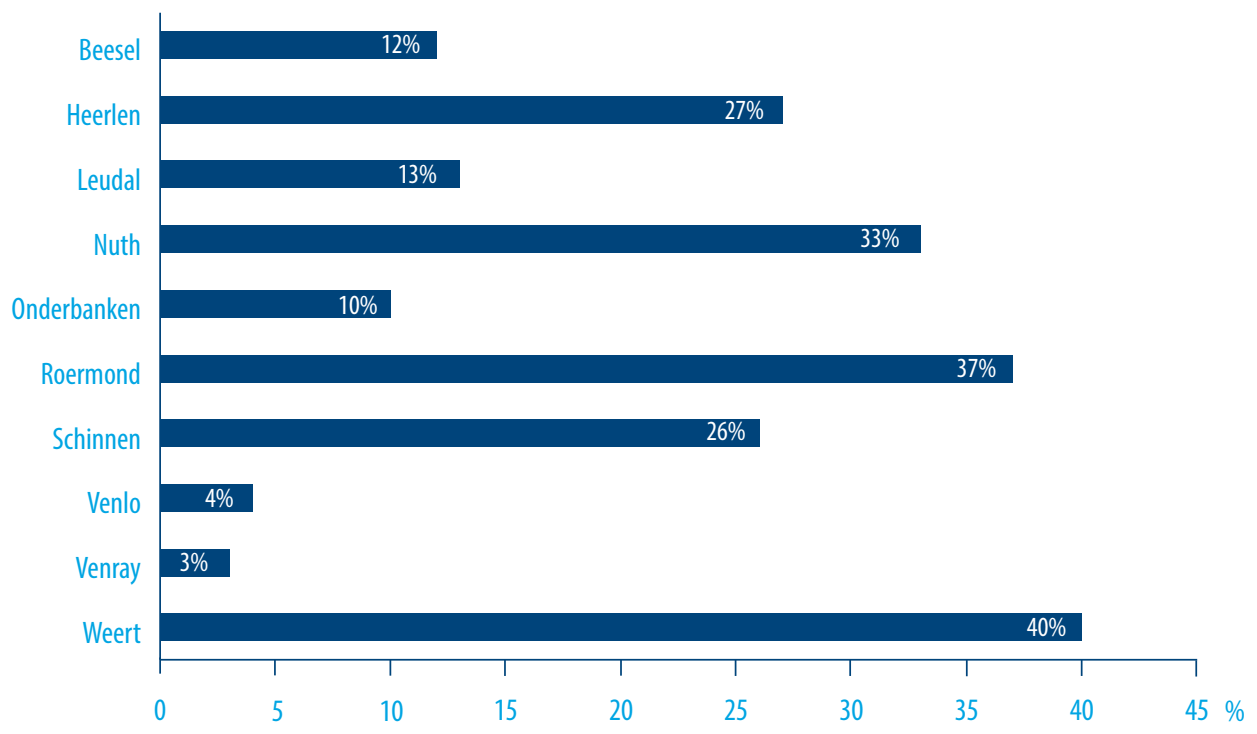

Bron: ROA, berekeningen op basis van microdata van het CBS

Uit Figuur 2 blijkt dat er behoorlijke verschillen in dit percentage zijn tussen gemeenten. Waar in Weert ongeveer $40 \%$ van de personen in een uitkeringsafhankelijke situatie deelneemt aan een re-integratietraject, ligt dit percentage in Venray ruim tien keer lager. In vijf gemeenten nemen ruim een derde van de personen in de bijstand of met een WW-uitkering deel aan een re-integratietraject. In drie andere gemeenten is dit een tiende van de uitkeringsafhankelijke en in de overige twee gemeenten ligt het percentage onder de $5 \%$.

In Limburg volgt bijna een vijfde van de WW- en bijstandsontvangers een re-integratietraject. Dit is vergelijkbaar met het percentage voor Nederland in het geheel, dat ligt ook op zo'n 20\%. Uit de beschrijvende statistieken komt overigens naar voren dat personen die in 2016 gedurende 12 maanden in de bijstand zitten vele malen vaker in een re-integratievoorziening volgen dan personen met WW ontvangen. ${ }^{9}$ In Bijlage $A$ is voor elke Limburgse gemeente het percentage van de WW- en bijstandsontvangers die een re-integratietraject gevolgd hebben weergegeven.

8 Hierbij is gebruik gemaakt van de variabele die aangeeft waar een persoon het meeste inkomen uit heeft.

9 Uit de beschrijvende statistieken komt naar voren dat ongeveer $2 \%$ van WW-ontvangers deelneemt aan een gemeentelijke re-integratie voorziening, tegenover $36 \%$ van de bijstandontvangers. Aangezien het percentage onder WW-ontvangers erg laag is, is er voor gekozen om in het verdere rapport alleen te focussen op de bijstandontvangers. 


\subsection{SRG data vanaf 2019}

Het ministerie van SZW heeft naar aanleiding van de CBS-rapportages, aangegeven niet tevreden te zijn met de uitvraag van re-integratievoorzieningen bij gemeenten. Het schakelschema tussen voorzieningen aangeboden door specifieke gemeentes en de classificatie van het CBS bleek ontoereikend waardoor de meeste voorzieningen terecht kwamen in de categorie 'overige voorzieningen' en er ook voorzieningen werden meegenomen in de re-integratie statistieken die eigenlijk geen re-integratievoorzieningen zijn. Voorbeelden van de laatste categorie zijn kinderopvang of inburgering. Deze posten moeten alleen worden opgegeven wanneer ze als extra maatwerk worden aangeboden in het kader van re-integratie of participatie en worden betaald vanuit het re-integratiebudget.

Om te komen tot een verbetering in de re-integratie statistiek heeft het CBS in opdracht van SZW in het eerste kwartaal van 2019 de aanlevering van gegevens over SRG-voorzieningen door gemeenten beoordeeld. Daarbij heeft het CBS in de uitvraag de typen voorzieningen uitgebreid, omdat in 2018 bleek dat bijna 90 procent van de voorzieningen als 'overig' werd getypeerd. Deze uitbreiding heeft plaatsgevonden in samenspraak met het ministerie van SZW en de gemeenten. Bij de beoordeling van de aanlevering van gegevens is vervolgens gelet op:

- Het kenmerk'omschrijving type voorziening': voor iedere gemeente zijn de aangeleverde voorzieningen op kwaliteit beoordeeld door de omschrijvingen van de voorzieningen te bekijken en die te vergelijken met het kenmerk'type voorziening'. Op basis daarvan is een terugkoppeling gegeven aan de gemeenten, indien nodig met het verzoek om de omschrijving aan te passen en/of de voorziening in te delen bij een ander type. In die gevallen werd ook om een herlevering gevraagd.

- Het kenmerk'aantal voorzieningen': op het moment dat er een opvallend verschil bestond tussen het aantal voorzieningen in januari 2019 en het aantal in de maand december 2018 is aan gemeenten gevraagd of daar een reden voor was. Als hiervoor geen logische verklaring gegeven kon worden of als er andere twijfels waren over de kwaliteit, werd er om een herlevering gevraagd.

Op basis van de hierboven beschreven analyses is een klein deel van de leveringen qua kwaliteit direct goedgekeurd. Echter hebben de meeste gemeenten een uitgebreide terugkoppeling per mail gekregen. Aan een kwart van hen is daarnaast extra telefonische toelichting gegeven, omdat de vragen over de kwaliteit dusdanig waren dat een mail niet voldoende was. De meeste gemeenten is bij de terugkoppeling om een herlevering gevraagd. Zij moesten alle maanden die tot dan toe (sinds januari 2019) waren aangeleverd nogmaals leveren. Bij ruim driekwart van alle gemeenten werd de eerste herlevering acceptabel bevonden. De rest werd verzocht een tweede herlevering te doen.

In aanvulling hierop heeft het CBS ook een kwaliteitsonderzoek uitgevoerd om de effecten van bovenbeschreven acties op de kwaliteit van de re-integratiestatistiek vast te stellen. Om te checken of de uitbreiding van het aantal typen voorzieningen leidt tot een betere indeling zijn specifieke voorzieningen in de tijd gevolgd en is nagegaan waar voorzieningen die in 2018 tot de categorie'overig' in 2019 werden ingedeeld. Resultaten lieten zien of de nieuwe indeling wel aansluit bij de praktijk van gemeenten. Ook is nagegaan of de voorzieningen die ook in 2019 tot categorie 'overig' behoren alsnog tot een andere categorie ingedeeld hadden kunnen worden. Uit het resultaat hiervan bleek dat in veel gevallen toch sprake was van een niet juiste codering van het type voorziening en dat er alsnog een type voorziening geleverd kon worden.

De kwaliteit van de aangeleverde bestanden verschilde verder aanzienlijk tussen gemeenten. Bovendien zijn er voorzieningen aangeleverd die eerder ten onrechte niet werden aangeleverd. Voorheen werden dus enerzijds te veel activiteiten als SRG-voorziening geleverd, anderzijds werden gegevens ten onrechte niet aangeleverd. De uitbreiding van het aantal typen voorzieningen en het nieuwe kenmerk'Omschrijving type voorziening' hebben gemeenten ertoe aangezet om de selecties ten behoeve van de SRG (opnieuw) te beoordelen. Daarnaast heeft het CBS gemeenten extra gewezen op juiste aanlevering. 
Hieronder wordt ingegaan op het effect van de uitbreiding van het aantal categorieën voor'type voorziening' en de intensievere uitvraag bij gemeenten om de cijfers. In Figuur 3 zijn de percentages specifieke re-integratievoorzieningen per gemeente in januari 2019 weergegeven.

FIGUUR 3 Percentage specifieke re-integratievoorzieningen per gemeente in januari 2019
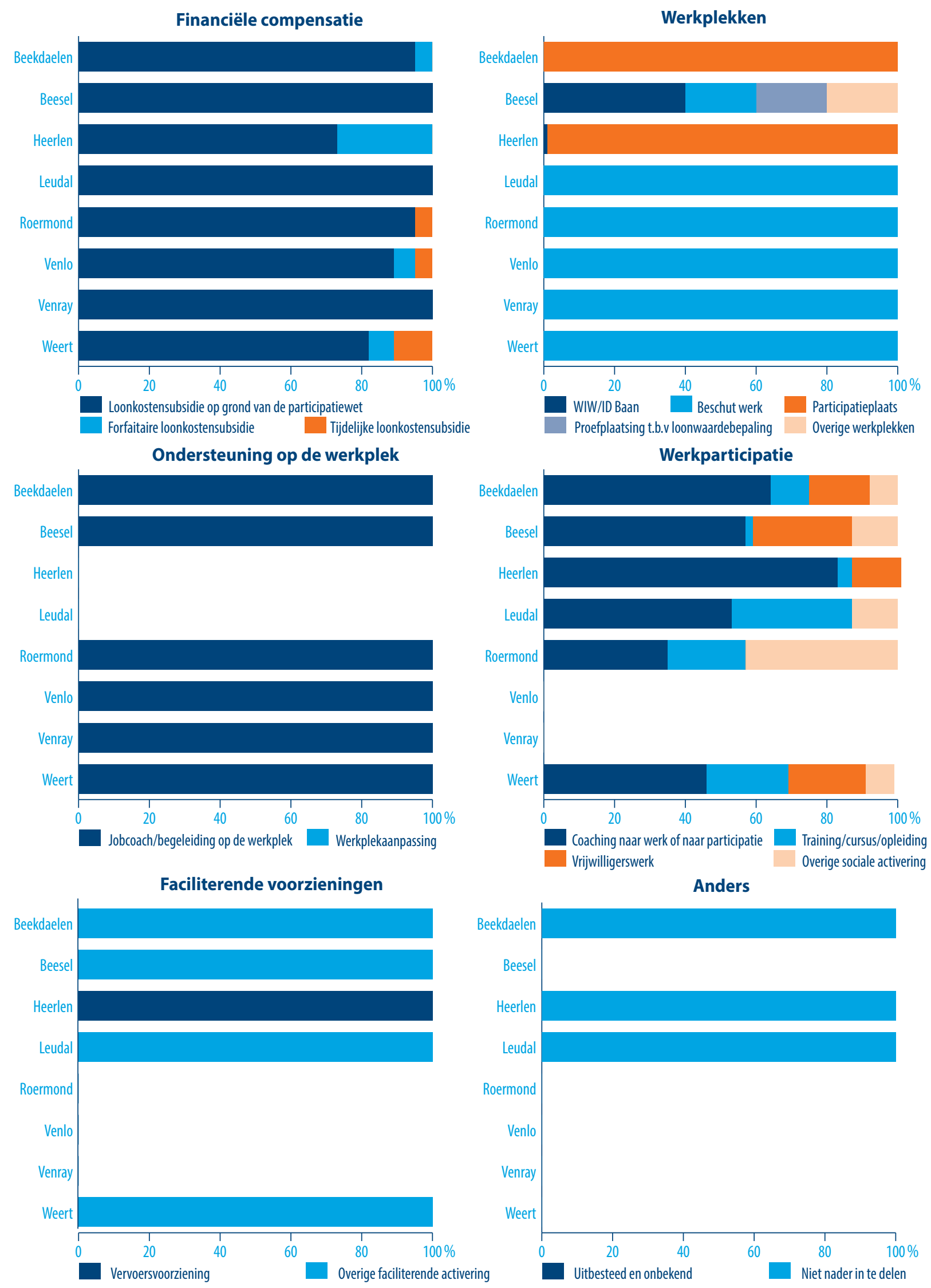

Bron: CBS (2019)

10 HOOFDSTUK 3 


\section{KWALITEIT LIMBURGSE GEMEENTELIJKE RE- INTEGRATIE DATA VAN HET CBS VOOR 2016-2017}

In dit hoofdstuk rapporteren wij drie verschillende kwaliteitschecks die we uitgevoerd hebben specifiek voor Limburgse gemeenten. Met deze kwaliteitschecks hopen we een goed beeld te krijgen van de kwaliteit van de binnen de 4Limburg beschikbare CBS data (2016-2017) voor specifieke Limburgse gemeentes. Het is noodzakelijk om inzichtelijk te krijgen voor welke gemeenten de 2016-2017 CBS data gebruikt kunnen worden om de effectiviteit van hun re-integratiebeleid te onderzoeken.

\subsection{Eerste kwaliteitscheck: vergelijking externe data}

Wij hebben een externe databron toegevoegd om de SRG-cijfers mee te vergelijken. Thönissen Management en Advies heeft de arrangementenmonitor ontwikkeld waarin op overzichtelijker manier het Sociaal Domein in kaart gebracht wordt. De arrangementenmonitor heeft onder andere informatie over het aantal huishoudens dat een bijstandsuitkering ontvangt en dat deelneemt aan re-integratievoorzieningen. ${ }^{10}$ Daarbij moet echter wel opgemerkt worden dat de externe bron de gegevens beschikbaar heeft op huishoudniveau, terwijl de gebruikte CBS-gegevens op individueel niveau gepresenteerd zijn.

Figuur 4 laat voor een selectie van Limburgse gemeenten het percentage van de bijstandsontvangers weer dat deelneemt aan een re-integratietraject in 2016." De oranje staven laten het percentage zien op basis van de CBS data. ${ }^{12}$ De blauwe staven laten het percentage zien gebaseerd op data van de Arrangementenmonitor.

Uit figuur 4 komt naar voren dat in bijna de helft van de gemeenten, het percentage bijstandsgerechtigden dat gebruikt maakt van een re-integratievoorziening volgens Thönissen Management en Advies aanzienlijk hoger (>10\%) ligt dan volgens de SRG-gegevens van het CBS. In de overige gemeenten is er sprake van minimale verschillen in de percentages $(\leq 10 \%)$. Aangezien gegevens op individueel en huishoudniveau worden vergeleken ${ }^{13}$, zijn kleine verschillen in de lijn der verwachting. Puur op basis van deze eerste kwaliteitscheck, lijkt de CBS-data voor de gemeenten Brunssum, Eijsden-Margraten, Horst aan de Maas, Maastricht, Valkenburg aan de Geul, Venlo en Venray redelijk. Wat betreft Venlo en Venray bestaan er wel zorgen over de kwaliteit gegeven het lage percentage bijstandsontvangers dat, gebaseerd op beide databronnen, een re-integratietraject gevolgd heeft. Gebaseerd op het feit dat vanuit beide databronnen het percentage bijstandsontvangers dat een re-integratietraject gevolgd heeft zo laag is, bestaat het vermoeden dat de gemeente Venlo, dat overigens ook de bijstand en participatieregistratie van Venray uitvoert, op een andere manier de koppeling van de eigen administratie naar de SRG-regelingen doorvoert dan andere gemeenten.

10 Een belangrijk verschil tussen de CBS data en de data van Thönissen Management en Advies is dat de laatstgenoemde de gegevens beschikbaar heeft op huishoudniveau, terwijl de gebruikte CBS-gegevens op individueel niveau gepresenteerd zijn.

11 Deze lijst is het gevolg van de beschikbaarheid van gemeenten in de Arrangementenmonitor.

12 Het betreft hierbij de met de Provincie Limburg overeengekomen gemeentes: Venlo, Roermond, Heerlen, Beesel, Venray, Weert, Leudal, Onderbanken-Nuth-Schinnen.

13 Aangezien het maatwerkbestand van het CBS ook informatie heeft over huishoudens, is gekeken hoe vaak het voorkomt dat in huishoudens met een bijstandontvanger, meerdere personen een bijstand ontvangen (exclusief de institutionele huishoudens). Dit bleek in ongeveer 15\% van de gevallen te zijn. In het merendeel van de huishoudens dat een bijstand ontvangt, is dit dan ook maar één persoon (85\%). 
FIGUUR 4 Percentage van de bijstandsontvangers dat deelneemt aan een re-integratietraject in 2016, naar bron (CBS versus Arrangementenmonitor)

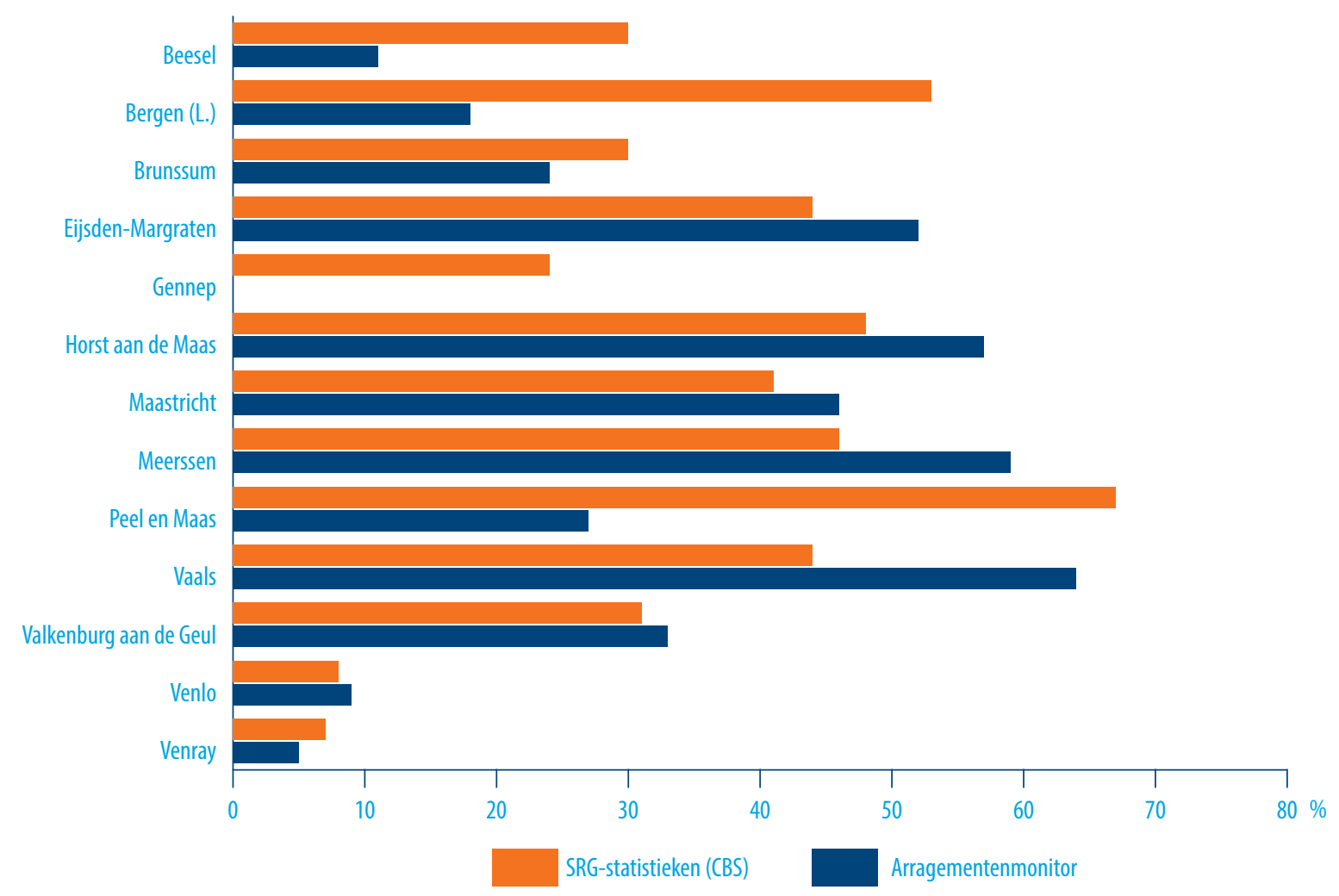

Bron: ROA (berekeningen op basis van microdata van het CBS) en Arrangementenmonitor

\subsection{Tweede kwaliteitscheck: specifieke re-integratie voorzieningen}

Zoals eerder beschreven is er ook informatie beschikbaar over specifieke re-integratievoorzieningen. Wanneer de verdeling van de specifieke voorzieningen per gemeente wordt bekeken, is echter te zien dat deze voornamelijk bestaan uit de 'overige voorziening'. Bij slechts enkele gemeenten worden andere inspanningen, zoals (tijdelijke) loonsubsidie en begeleiding op werkkring/job-coach gerapporteerd. Dit is het geval bij de gemeente Venlo en Venray. Vanwege lage aantallen mogen de meeste cijfers van de specifieke inspanningen niet worden gepubliceerd ( $\leq 10$ personen). De enige gemeentelijk inspanning die redelijk gevuld lijkt te zijn, is het kenmerk dat de overige gemeentelijke inspanningen meet, namelijk 'overige voorziening'. Voor alle gemeenten, met uitzondering van Venlo en Venray, is meer dan de helft van de gemeentelijke inspanningen geclassificeerd als 'overige voorziening'.

Het is niet plausibel dat de andere specifieke gemeentelijke inspanningen zo weinig worden ingezet. Deze bevindingen wijzen er dus op dat de kwaliteit van de metingen van de specifieke re-integratie voorzieningen in 2016 en 2017 verre van optimaal is geweest. De meeste gemeenten waren nog niet zover om de tabellen zo in te richten dat in alle gevallen de juiste voorzieningen werden aangeleverd, wat heeft geleid tot het relatief grote aandeel voorzieningen dat is ingedeeld in overige inspanningen. Wederom kan geconcludeerd worden dat de CBS-data voor Venlo en Venray het meest betrouwbaar is.

\subsection{Derde kwaliteitscheck: vergelijking voor en na verbetering}

Figuur 5 en Figuur 6 laten de verschillen in het aantal re-integratievoorzieningen per gemeente zien voor en na de verbeteringen die door het CBS zijn doorgevoerd. ${ }^{14}$ Deze verschillen zijn allereerst tot stand gekomen doordat vóór de verbetering ook voorzieningen werden meegenomen in de re-integratie statistieken die

14 De kwaliteitscheck waarbij het aantal voorzieningen in december 2018 en januari 2019 vergeleken worden heeft betrekking op alle bijstands- en werkloosheidsuitkeringsontvangers. Dit heeft te maken met de beschikbare data van het CBS.

12 HOOFDSTUK 4 
eigenlijk geen re-integratievoorzieningen waren. Daarnaast is er een betere koppeling tussen de administraties van gemeentes en de onderscheiden re-integratievoorzieningen door het CBS. Figuur 5 laat allereest het totaal aantal re-integratie inspanningen per gemeente zien in december 2018 en januari 2019. Eigenlijk zouden er, als de methode voor het classificeren van re-integratievoorzieningen niet veranderd was, geen grote verschillen moeten zijn tussen deze twee aaneengesloten maanden. Echter, in Figuur 5 zien we een aantal gemeenten waarbij de totale aantallen aanzienlijk verschillen. Dit is het geval bij Heerlen en Roermond. Er zijn echter ook gemeenten met minimale verschillen. Wederom horen Venlo en Venray tot de gemeenten met weinig verschillen, maar ook in Beekdaelen, Beesel en Leudal zijn de verschillen minimaal. De gemeente Venlo is de enige gemeente met minder dan $10 \%$ verschil in het aantal re-integratievoorzieningen tussen december 2018 en januari 2019.

FIGUUR 5 Totaal aantal re-integratie en participatievoorzieningen in december 2018 en januari 2019

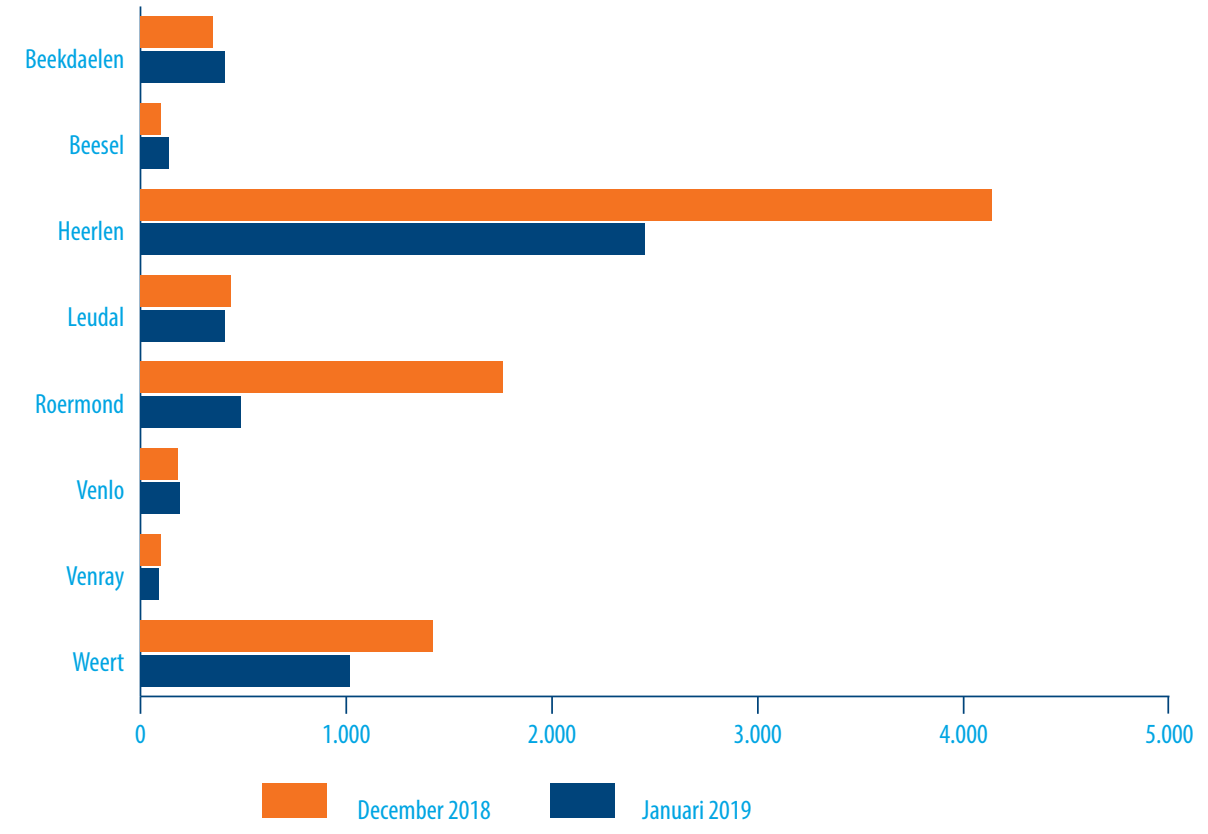

Bron: CBS $(2018,2019)$

In Figuur 6 zijn de aantallen per soort re-integratievoorziening weergegeven. Hieruit komt naar voren dat er wat betreft de inspanningen die gericht zijn op financiële compensatie en werkplekken kleine verschillen waarneembaar zijn tussen december 2018 en januari 2019 bij het merendeel van de gemeenten. De data voor de verbetering lijken bij deze specifieke inspanningen dan ook redelijk betrouwbaar.

Echter, vóór de verbetering werden veel van de inspanningen ingedeeld bij de categorie 'overige inspanning', terwijl dit na de verbetering veel minder te zien is. Ook valt op dat in januari 2019 twee categorieën zijn toegevoegd die eerder niet bestonden of amper waren gevuld, namelijk werkparticipatie ${ }^{15}$ en faciliterende voorzieningen. ${ }^{16}$ Hoewel bij een tweetal specifieke inspanningen er dus relatief kleine verschillen zijn tussen gemeenten, zijn bij de andere inspanningen wel grote verschillen te zien. Ervan uitgaande dat de gegevens uit 2016 en 2017 vergelijkbaar zijn met de gegevens uit 2018, is het aannemelijk dat de kwaliteit van onze data ook ontoereikend is.

15 Onder werkparticipatie vallen de volgende inspanningen: coaching naar werk of naar participatie, training/cursus/ opleiding, vrijwilligerswerk en overige sociale activering.

16 Onder faciliterende voorzieningen vallen de volgende twee inspanningen: vervoersvoorziening en overige faciliterende activering. 
FIGUUR 6 Aantal specifieke re-integratievoorzieningen in december ' 18 en januari ' $19^{17}$
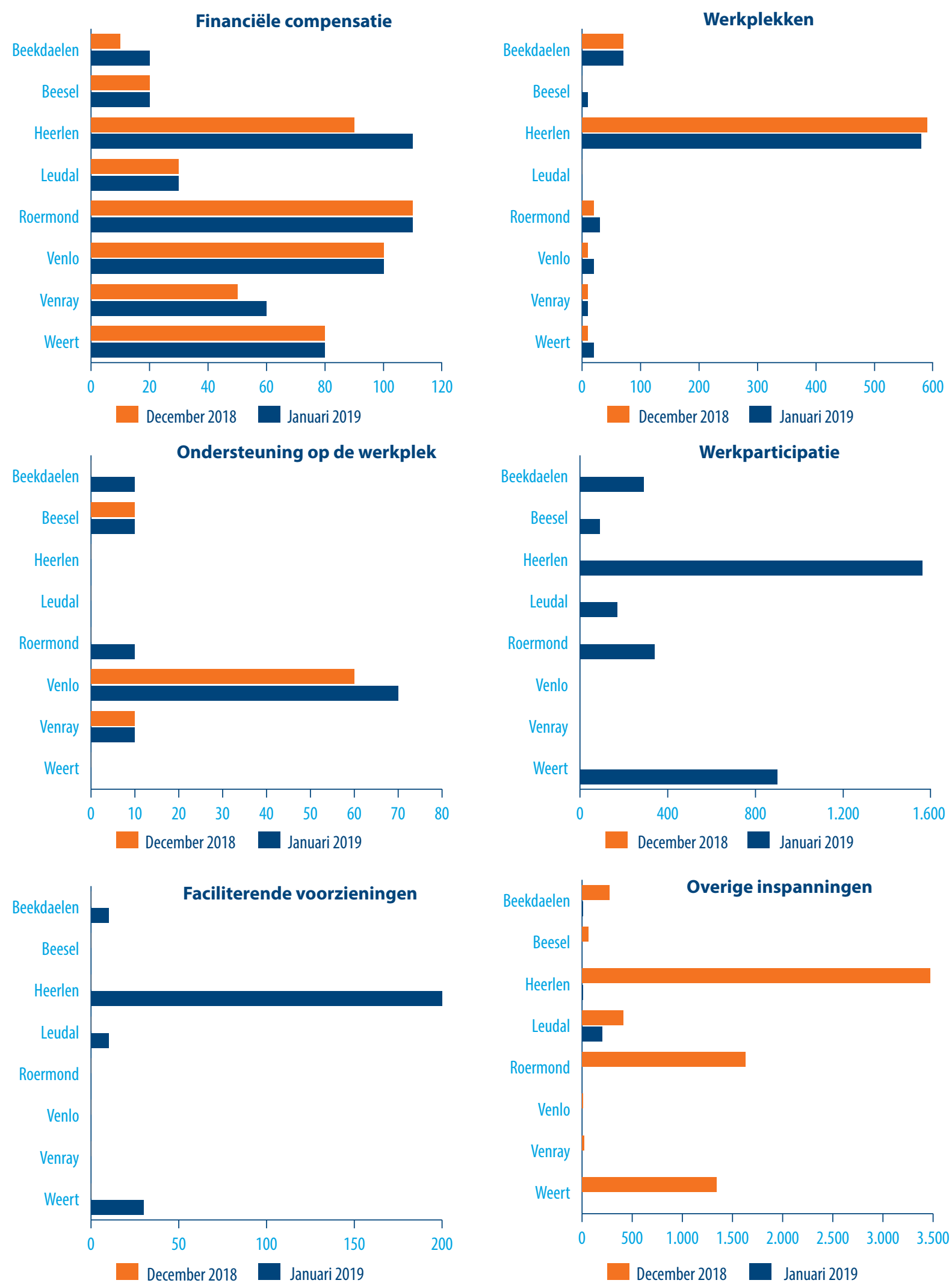

Bron: CBS $(2018,2019)$

17 De gemeenten Onderbanken, Nuth en Schinnen zijn per 1 januari 2019 gefuseerd in de gemeente Beekdaelen. In Figuur 2 zijn de gegevens van de gemeenten Onderbanken, Nuth en Schinnen van december 2018 samengevoegd. 
De voorgaande kwaliteiscontroles, met uitzondering van de eerste kwaliteitscheck, zijn telkens uitgevoerd op een groep gemeenten die in afstemming met de Provincie Limburg is gekozen. De mogelijkheid bestond dat deze gemeenten te groeperen waren in gemeenten met kwalitatief goede data en gemeenten met minder goede data. Uit de twee voorgaande kwalitetiscontroles is echter naar voren gekomen dat zo'n eenduidige groepering erg lastig te maken is. De enige twee gemeenten die op alle kwaliteitschecks positief scoren zijn de gemeenten Venlo en Venray. Echter, juist bij deze twee gemeenten bestaan zorgen over de kwaliteit van de data gegeven het lage percentage bijstandsontvangers dat, gebaseerd op zowel de SRG data als ook op de data van Thönissen Management en Advies, een re-integratietraject gevolgd heeft. Bij de overige gemeenten komt geen duidelijk beeld naar voren. Figuur 6 laat zien dat de gemeenten die we nu onder de loep nemen in 2018 (en daarmee ook in 2016/2017) naar alle waarschijnlijkheid verschillend zijn omgegaan met de categorie 'overig' en dat ook het aantal gerapporteerde voorzieningen per gemeente verschilt en dat dit aantal niet één op één samenhangt met de grootte van de gemeente.

Al met al blijkt dat met de huidige data het niet mogelijk is om de effectiviteit van specifieke gemeentelijke re-integratie inspanningen vast te stellen. Daarvoor zijn de aantallen per gemeente te laag en te onbetrouwbaar. Daarentegen kunnen de geleverde variabelen wel inzicht geven in de deelname aan een re-integratietraject zoals indertijd aangegeven door gemeenten en de kans op uittreding uit een uitkeringsafhankelijke positie. Hier hoort wel de kanttekening bij dat in het verleden ook door gemeenten voorzieningen zijn gerapporteerd die geen re-integratievoorzieningen zijn en dat individuele gemeenten hier verschillend mee om kunnen zijn gegaan. Enige voorzichtigheid in de interpretatie van resultaten is hiermee dus geboden.

\subsection{Samenvatting kwaliteit SRG-data voor Limburgse gemeenten in 2016/2017}

TABEL 2 Overzicht uitkomsten kwaliteitschecks SRG-data 2016/2017 voor de Limburgse gemeenten

\begin{tabular}{|l|l|l|l|}
\hline Gemeente & $\begin{array}{l}\text { Check 1 } \\
\text { Vergelijking \% deelname met } \\
\text { externe data, 2016* }\end{array}$ & $\begin{array}{l}\text { Check 2 } \\
\text { Categorie overige voorzieningen } \\
\text { in 2016 }\end{array}$ & $\begin{array}{l}\text { Check 3 } \\
\text { Verschil totaal aantal re- } \\
\text { integratievoorzieningen tussen dec } \\
2018 \text { en jan } 2019\end{array}$ \\
\hline $\begin{array}{l}\text { Beekdaelen (Onderbanken-Nuth-Schinnen) } \\
\text { Beesel }\end{array}$ & $<10 \%$ & $>50 \%$ & $>10 \%$ \\
\hline Heerlen & & $>50 \%$ & $>10 \%$ \\
\hline Leudal & & $>50 \%$ & $>10 \%$ \\
\hline Venlo & $<10 \%$ & $>50 \%$ & $>10 \%$ \\
\hline Venray & $<10 \%$ & $<50 \%$ & $<10 \%$ \\
\hline Roermond & & $<50 \%$ & $>10 \%$ \\
\hline Weert & & $>50 \%$ & $>10 \%$ \\
\hline
\end{tabular}

* Voor de lege velden is geen data beschikbaar in de arrangementenmonitor.

Bron: ROA (berekeningen op basis van microdata van het CBS), Arrangementenmonitor, CBS

Tabel 2 geeft een overzicht van de drie eerder beschreven kwaliteitschecks. Uit de tabel blijkt dat alleen Venlo op alle drie de checks relatief goed scoort. Venray volgt op de voet maar heeft net iets meer dan $10 \%$ verschil in het aantal re-integratievoorzieningen tussen december 2018 en januari 2019. Echter, het zijn ook precies deze twee gemeenten die een relatief laag percentage bijstandsuitkeringsontvangers tellen dat überhaupt deelneemt aan een of meerdere gemeentelijke voorzieningen (onder de $5 \%$ ). Dit kan ofwel het gevolg zijn van een bewust beleid waarin bijstandsontvangers wat meer ruimte krijgen om zelf hun weg naar arbeid terug te vinden, maar het kan ook zo zijn dat de CBS-cijfers (als ook de cijfers van Thönissen Management en Advies) de gerealiseerde re-integratievoorzieningen (in de hele periode 2016-2019) niet goed in kaart kunnen brengen. Terwijl in Beesel de cijfers van het CBS vergelijkbaar zijn met die van Thönissen Management en Advies (voor 2016), is het percentage re-integratieregelingen dat terecht is gekomen in de categorie overig in 2016 relatief hoog. Ook wijken de cijfers over totaal aangeboden re-integratietrajecten in december 2018 en januari 2019 meer dan 10\% af. Voor Heerlen, Leudal, Roermand en Weert, geldt dat de kwaliteitscheck op basis van de 
externe data niet mogelijk was. De overige twee checks suggereren echter dat de kwaliteit van de CBS data voor de jaren 2016 en 2017 niet voldoende is.

We concluderen op basis van deze bevindingen dat het met de beschikbare gegevens niet mogelijk is om vast te stellen welke specifieke re-integratie inspanningen de kans op werk vergroten. De kwaliteit van deze gegevens is daarvoor te laag. Dit heeft als nadeel dat we alleen kunnen nagaan of het volgen van een re-integratiespanning een effect heeft op de kans op herintreding. Bij deze gegevens moet echter ook een kanttekening worden geplaatst. Het CBS heeft namelijk, tijdens de verbeterslag, ontdekt dat gemeenten voorzieningen hebben gerapporteerd die strikt genomen geen re-integratie voorzieningen zijn. De verschillende gemeenten zijn hier anders mee omgegaan, waardoor ook de gegevens van de totale re-integratievoorzieningen met voorzichtigheid moeten worden behandeld. Analyses die gebruik maken van de CBS data over gemeentelijke re-integratievoorzieningen, zouden daarom alleen gebruik moeten maken van informatie over gemeenten waarbij slechts een relatief klein verschil waargenomen is tussen het totaal aantal re-integratievoorzieningen in december 2018 en januari 2019. 


\section{ANALYSES}

In dit hoofdstuk laten we zien wat er met de beschikbare CBS data van 2016/2017 wel mogelijk is. ${ }^{18}$ Voor de gemeenten waarbij uit de drie kwaliteitscontroles naar voren kwam, dat de gegevens tot op zekere hoogte betrouwbaar zijn, is gekeken naar de relatie tussen deelname aan een re-integratie voorzieningen in 2016 en de kans op werk in december 2017. De personen in deze analyses hebben in heel 2016 een bijstandsuitkering ontvangen.

TABEL 3 Deelname aan een re-integratie inspanning en de kans op werk (zonder uitkering)

\begin{tabular}{|c|c|c|}
\hline Afhankelijke variabele: werk zonder uitkering in dec 2017 & (a) & (b) \\
\hline \multirow[t]{2}{*}{ Deelgenomen aan een reintegratie inspanning in 2016} & $0.092^{* * *}$ & $0.068^{* * *}$ \\
\hline & $(0.011)$ & $(0.011)$ \\
\hline \multirow[t]{2}{*}{ Vrouw } & & $-0.039^{* * *}$ \\
\hline & & $(0.006)$ \\
\hline \multirow[t]{2}{*}{ Leeftijd } & & $-0.010^{* * *}$ \\
\hline & & $(0.002)$ \\
\hline \multirow[t]{2}{*}{ Leeftijd kwadraat } & & $0.000^{* * *}$ \\
\hline & & $(0.000)$ \\
\hline \multirow[t]{2}{*}{ 1e generatie allochtoon } & & 0.007 \\
\hline & & $(0.007)$ \\
\hline \multirow[t]{2}{*}{ 2e generatie allochtoon } & & -0.014 \\
\hline & & $(0.011)$ \\
\hline \multirow[t]{2}{*}{ Hoogstvoltooide opleiding: Midden } & & $0.022^{* * *}$ \\
\hline & & $(0.008)$ \\
\hline \multirow[t]{2}{*}{ Hoogstvoltooide opleiding: Hoog } & & 0.022 \\
\hline & & $(0.015)$ \\
\hline \multirow[t]{2}{*}{ Hoogstvoltooide opleiding: Missende waarde } & & 0.007 \\
\hline & & $(0.013)$ \\
\hline \multirow[t]{2}{*}{ Constante } & $0.036^{* * *}$ & $0.352^{* * *}$ \\
\hline & $(0.003)$ & $(0.051)$ \\
\hline Observaties & 4,043 & 4,043 \\
\hline R-kwadraat & 0.016 & 0.057 \\
\hline \multicolumn{3}{|l|}{ Standaard fouten tussen haakjes } \\
\hline${ }^{* * *} p<0.01,{ }^{* *} p<0.05,{ }^{*} p<0.1$ & & \\
\hline
\end{tabular}

Bron: ROA, bewerkingen op basis van microdata van het CBS

18 Deze analyses hebben alleen betrekking op de gemeenten die een vergelijkbaar aantal re-integratievoorzieningen aan het CBS hebben gerapporteerd in december 2018 en januari 2019 (zie Bijlage A, Tabel A3). 
In een eerste stap in de analyse is gekeken naar het effect van deelname aan een re-integratie inspanning in 2016 op de kans op werk in december 2017. Daarbij worden personen die in december 2017 gebruik maakten van een gemeentelijke inspanning buiten beschouwing gelaten. Ook wordt alleen gekeken naar de personen die in december 2017 werk hadden én geen bijstandsuitkering meer ontvingen. Uit deze eerste analyse (zie model a in Tabel 3) komt naar voren dat het volgen van een re-integratie traject significant gerelateerd is aan het vinden van een baan. Echter, wordt er maar slechts een klein deel van het vinden van een baan in december 2017 verklaard door de deelname aan een gemeentelijke inspanning (1,6\%).

Door rekening te houden met allerlei achtergrondkenmerken, zoals opleidingsniveau, geslacht en leeftijd, kunnen we de relatie tussen deelname aan een gemeentelijke inspanning en de kans op re-integratie beter isoleren. Dit is dan ook gedaan in model b van Tabel 3. Hieruit komt naar voren dat de kans op werk nog steeds groter is wanneer een bijstandsgerechtigde heeft deelgenomen aan een re-integratie inspanning. 


\section{REFLECTIE OP VERANDERSLAG}

In Hoofdstuk 3 is uitgebreid beschreven welke nieuwe ontwikkelingen er zijn in de re-integratiestatistiek van het CBS. Vanaf begin 2019 is gestart met de kwaliteitsverbetering van de gemeentelijke data. Hoewel deze veranderslag pas zeer recentelijk is ingezet, reflecteren we in dit hoofdstuk op deze veranderingen. De gemeentelijke re-integratie gegevens van vóór 2019 laten duidelijk zien dat een verbetering nodig was. Dit is ook onderkend door het ministerie van SZW waarnaar in samenspraak met het CBS aanpassingen zijn gedaan in de uitvraag van de gegevens.

Eerder kwamen vele voorzieningen terecht in de type voorziening 'overig'. Mede door de uitbreiding van het aantal categorieën in dit kenmerk, kunnen gemeenten preciezer rapporteren wat voor soort type re-integratie voorziening het betreft. Zo ontbrak in de eerdere categorieën, voorzieningen die gericht zijn op de overgang naar werk en participatie, zoals coaching, vrijwilligerswerk, training, cursus en opleiding. Uit de recentelijk verschenen SRG-cijfers van 2019, is te zien dat de meeste Limburgse gemeenten hier een aanzienlijk deel van hun voorzieningen in heeft geclassificeerd. Gemeenten hebben alsnog de optie om de voorzieningen in een overige categorie te zetten. Hierbij geldt dat deze 'overige' voorzieningen dan wel meer gespecificeerd worden, zo zijn de volgende categorieën toegevoegd in 2019: 'overige werkplekken', 'overige sociale activering' en 'overige faciliterende voorziening'. Hoewel de voorzieningen dan alsnog vallen onder 'overig', is al wel meer bekend over het doel van de inspanning. In meerdere Limburgse gemeenten komen voorzieningen nog terecht in deze 'overige' categorieën.

Het SRG-verandertraject heeft in het algemeen gezorgd voor een meer gedetailleerde uitvraag, waardoor gemeenten in staat zijn om hun voorzieningen beter in te delen, mits gemeenten voldoende op de hoogte zijn van de indeling. Geconditioneerd op dat laatste punt, zal deze verbetering van de uitvraag moeten leiden tot een betere kwaliteit. De uitvraag sluit immers beter aan op de realiteit. Kanttekening die hierbij geplaatst dient te worden, is dat in de Limburgse gemeenten die in dit rapport onder loep zijn genomen er enkele type voorzieningen zijn die in geen van deze gemeenten ingezet lijken te worden. Dit kan uiteraard ook te maken hebben met de focus van het beleid. Het is belangrijk om dit duidelijk te krijgen.

Naast de uitbreiding van het aantal typen voorzieningen, worden gemeenten ook gevraagd naar de omschrijving van de voorziening uit hun eigen administratie. Deze omschrijving samen met de type re-integratievoorziening ingedeeld in de CBS-classificatie, hebben gemeenten ertoe aangezet hun re-integratie gegevens (opnieuw) te beoordelen. Om het verandertraject optimaal te laten verlopen, heeft het CBS gemeenten feedback gegeven per mail en indien nodig telefonisch. Deze gemeenten werd ook gevraagd om hun gemeentelijke re-integratie statistieken nogmaals te leveren. Dat de meeste gemeenten uitgebreide terugkoppeling nodig hadden en er door het CBS om herlevering is gevraagd, suggereert dat de gegevens van vóór het verandertraject kwalitatief niet goed waren. Gemeenten hebben er nu met veel aandacht naar gekeken, waardoor het in 2019 zeer waarschijnlijk aanzienlijk is verbeterd. Dit is ook terug te zien in de kwaliteitschecks die het CBS heeft gedaan.

Het lage percentage uitkeringsafhankelijken (bijstand en ww) dat, op basis van zowel de SRG-cijfers van voor en na de verbeterslag van het CBS, gerapporteerd is voor de gemeenten Venlo en Venray, schept het vermoeden dat er nog wel verdere verbeteringen mogelijk zijn. Omdat deze gemeenten zowel een relatief laag percentage 'overige voorzieningen' had als ook een vergelijkbaar totaal aantal voorzieningen in december 2018 en 
januari 2019, kunnen we niet met zekerheid zeggen of op dit punt voldoende is doorgevraagd. Dit resultaat uit onze analyse is wellicht nog een uitzoekpunt dat door het CBS kan worden opgepakt.

Concluderend heeft het SRG-verandertraject de gegevens over de re-integratievoorzieningen sterk verbeterd. De gemeentelijk re-integratie gegevens van 2019 zijn dan ook veel bruikbaarder dan de SRG-gegevens van voor de verandering. Echter is het van belang dat het CBS gemeenten blijft attenderen op het goed leveren van de data. Er is nu zeer uitgebreid feedback gegeven door het CBS en gecheckt of de nieuwe cijfers plausibel waren. De vraag is of dit in de toekomst ook zo intensief blijft. Het is naar onze mening belangrijk om de uitvraag goed te blijven monitoren. Het aantal aan re-integratievoorzieningen is immers aan verandering onderhevig. Hiervoor dienen de kwaliteitschecks regelmatig door het CBS herhaald te worden. Ook moet bij de gemeenten kennis over het correct leveren van de re-integratiestatistieken blijven bestaan. Het wordt dan mogelijk om de effectiviteit van re-integratievoorzieningen verder uit te zoeken.

Hoewel deze data niet gebruikt kan worden binnen het huidige 4Limburg project, is het in de toekomst wel mogelijk uitspraken te doen over de effectiviteit van het re-integratiebeleid van specifieke gemeentelijke voorzieningen. ${ }^{19}$ Dit zal zeer waardevol zijn voor het vergroten van de effectiviteit van het re-integratiebeleid.

19 Overigens is de beschikbaarheid van individuele data met betrekking tot deelname aan re-integratievoorzieningen alleen niet voldoende om causale uitspraken te doen vanwege selectie in deelname aan re-integratievoorzieningen. Echter, zonder deze data is onderzoek helemaal niet mogelijk. 


\section{BIJLAGE A}

TABEL A1 Percentage WW- en bijstandontvangers in een re-integratietraject overige Limburgse gemeenten, 2016

\begin{tabular}{|l|c|}
\hline Beek & $9 \%$ \\
\hline Bergen (L.) & $18 \%$ \\
\hline Brunssum & $18 \%$ \\
\hline Echt-Susteren & $16 \%$ \\
\hline Eijsden-Margraten & $14 \%$ \\
\hline Gennep & $10 \%$ \\
\hline Gulpen-Wittem & $24 \%$ \\
\hline Horst aan de Maas & $13 \%$ \\
\hline Kerkrade & $19 \%$ \\
\hline Landgraaf & $21 \%$ \\
\hline Maasgouw & $10 \%$ \\
\hline Maastricht & $25 \%$ \\
\hline Meerssen & $17 \%$ \\
\hline Mook en Middelaar & $6 \%$ \\
\hline Nederweert & $5 \%$ \\
\hline Peel en Maas & $17 \%$ \\
\hline Roerdalen & $32 \%$ \\
\hline Roermond & $37 \%$ \\
\hline Simpelveld & $35 \%$ \\
\hline Sittard-Geleen & $11 \%$ \\
\hline Stein & $16 \%$ \\
\hline Vaals & $26 \%$ \\
\hline Valkenburg aan de Geul & $14 \%$ \\
\hline Voerendaal & $24 \%$ \\
\hline Bron: ROA, berekeningen op basis van microdata van het CBS \\
\hline
\end{tabular}


TABEL A2 Overzicht uitkomsten kwaliteitschecks SRG-data 2016/2017 voor de Limburgse gemeenten

\begin{tabular}{|c|c|c|c|}
\hline Gemeente & $\begin{array}{c}\text { Check } 1 \\
\text { Vergelijking \% deelname met externe } \\
\text { data, } 2016^{*}\end{array}$ & $\begin{array}{l}\text { Check } 2 \\
\text { Categorie overige voorzieningen in } \\
2016\end{array}$ & $\begin{array}{c}\text { Check } 3 \\
\text { Verschil totaal aantal re- } \\
\text { integratievoorzieningen tussen dec } \\
2018 \text { en jan } 2019\end{array}$ \\
\hline Beek & & $>50 \%$ & $>10 \%$ \\
\hline Bergen & $>10 \%$ & $>50 \%$ & $<10 \%$ \\
\hline Brunssum & $<10 \%$ & $>50 \%$ & $>10 \%$ \\
\hline Echt-Susteren & & $>50 \%$ & $>10 \%$ \\
\hline Eijsden-Margraten & $<10 \%$ & $>50 \%$ & $>10 \%$ \\
\hline Gennep & $>10 \%$ & $>50 \%$ & $<10 \%$ \\
\hline Gulpen-Wittem & & $>50 \%$ & $>10 \%$ \\
\hline Horst aan de Maas & $<10 \%$ & $>50 \%$ & $>10 \%$ \\
\hline Kerkrade & & $>50 \%$ & $<10 \%$ \\
\hline Landgraaf & & $>50 \%$ & $>10 \%$ \\
\hline Leudal & & $>50 \%$ & $<10 \%$ \\
\hline Maastricht & $<10 \%$ & $>50 \%$ & $>10 \%$ \\
\hline Meerssen & $>10 \%$ & $>50 \%$ & $>10 \%$ \\
\hline Mook en Middelaar & & $>50 \%$ & $>10 \%$ \\
\hline Nederweert & & $>50 \%$ & $>10 \%$ \\
\hline Peel en Maas & $>10 \%$ & $>50 \%$ & $>10 \%$ \\
\hline Roerdalen & & $>50 \%$ & $>10 \%$ \\
\hline Simpelveld & & $>50 \%$ & $<10 \%$ \\
\hline Sittard-Geleen & & $>50 \%$ & $>10 \%$ \\
\hline Stein & & $>50 \%$ & $<10 \%$ \\
\hline Vaals & $>10 \%$ & $>50 \%$ & $>10 \%$ \\
\hline Valkenburg aan de Geul & $<10 \%$ & $>50 \%$ & $>10 \%$ \\
\hline Voerendaal & & $>50 \%$ & $<10 \%$ \\
\hline
\end{tabular}

* Voor de lege velden is geen data beschikbaar in de arrangementenmonitor.

Bron: ROA (berekeningen op basis van microdata van het CBS), Arrangementenmonitor, CBS

TABEL A3 Gemeenten waarbij SRG-gegevens in januari 2019 (sterk) overeenkomen met die van de december 2018

\begin{tabular}{|l|c|c|c|}
\hline Gemeenten & Groeipercentage & Januari 2019 & December 18 \\
\hline Bergen (L.) & $6 \%$ & 180 & 170 \\
\hline Gennep & $0 \%$ & 110 & 110 \\
\hline Kerkrade & $-6 \%$ & 660 & 700 \\
\hline Leudal & $-9 \%$ & 400 & 440 \\
\hline Mook en Middelaar & $0 \%$ & 10 & 10 \\
\hline Simpelveld & $-6 \%$ & 160 & 170 \\
\hline Stein (L.) & $-8 \%$ & 110 & 120 \\
\hline Venlo & $0 \%$ & 180 & 180 \\
\hline Voerendaal & $-6 \%$ & 170 & 180 \\
\hline
\end{tabular}

Bron: CBS $(2018,2019)$ 